\title{
Welfare Economics in Albania in Terms of Gross Domestic Product
}

\author{
Xhensila Abazi \\ Lecturer, Faculty of Economy, "Aleksandër Xhuvani "University, Albania \\ xhensila.abazi@hotmail.com
}

\section{Doi:10.5901/ajis.2014.v3n4p343}

\begin{abstract}
This paper is an attempt to explain the welfare economics in terms of GDP using the expenditure approach of GDP estimating. Thus, the assumption is that GDP measures the economic welfare and trying to identify which indicators does contribute more on it using the expenditure approach. The data used for this study has spanned over the period of 1992 till 2012 and taken from the World Development Indicators. The model consists of five variables including GDP, HCE, GE,GFCF, and T. The methodology to test the impact of these variables on GDP has been limited to the least squares method. The co-integration of the variables has been ascertained through application of graphical approach, correlogram test and Ljung - Box statistic. It is found to hold in the long run. The findings indicate that Albania's welfare economics is positively affected by household consumption expenditure, government expenditure as well as gross fixed capital formation of private sector while trade has a negative impact.
\end{abstract}

Keywords: Welfare issues, gross domestic product, consumption expenditure, government expenditure, gross fixed capital formation, trade.

\section{Introduction and Literature Review}

How well various member of society live depends on how society deals with efficiency and equity. The actual outcome depends on choices by individuals and on government actions. The general welfare is a multidimensional concept and depends on the national culture of the dominant group within each state. To most people, the term welfare refers to the government's payments to poor people. No such meaning is implied when economists employ the term. Economists use welfare to refer to the well-being of various groups such as consumers and producers. They call an analysis of the impact of a change on various groups' well-being a study of welfare economics (Perloff, 1999). By definition, welfare economics is a branch of economics that uses microeconomic techniques to evaluate well-being from allocation of productive factors to desirability and economic efficiency within an economy, often relative to competitive general equilibrium. It analyzes social welfare, however measured in terms of activities of the individuals that compose the theoretical society considered (Deardoff, 2006).

The concept of economic welfare is employed to focus on the impact of economic growth on the material living standards of households and individual citizens, rather than on production. It includes in kind services provided by government such as subsidized health care and educational services, while excluding defense spending and general government expenses which do not directly contribute to household consumption (Jacobs \& Slaus, 2010).

As a first step in studying welfare issues, many economists use a narrow value criterion, called the Pareto principle or Pareto efficiency (any allocation such that any reallocation would harm at least one person) (Perloff, 1999). Another aspect of welfare treats income/goods distribution, including equality, as a further dimension of welfare (Little, 1950). As a welfare measure has been used, $W=$ consumer surplus + producer surplus, that weights benefits and losses to consumers and producers equally (Perloff, 1999).

Amore general approach to measure welfare one can refer to the social welfare functions which is a rule $F\left(a_{1}, \ldots, a_{2}\right)$ that assigns a social preference that is, $F\left(a_{1}, \ldots, a_{2}\right) \in\{-1,0,1\}$, to every possible profile of individual preferences $\left(a_{1, \ldots .,} a_{2}\right) \in$ $\{-1,0,1\}$. The classical utilitarian welfare function states that the social welfare function is the sum of individual utilities functions. Another interesting function is the minimax or Rawlsian (1971) function. Social utility equals the utility value of the worst-off individual. It follows that the social planning problem becomes one of maximizing the utility of the worst-off individual (Mas-Collel, Andreu, Whinston, \& Green, 1995). The work of the economist Amartya Sen(1979) seeks to relate social welfare to the value of total income or total consumption. In that matter one of the approaches consists in considering a representative agent who consumes $X$ and who's utility $U(X)$ is identified to social welfare. Amartya Sen 
(1982) is proposing a different kind of indicator based of the Gini index: $W_{\text {Gini }}=$ Income $_{\text {per capita }}(1-G)$ where $G$ is the Gini index ${ }^{1}$. Nowadays there are many wealth indicators that combine various domain indicators of economic, social and environmental performance. Prominent indicators include the Human Development Index (HDI) and the indicators computed by Osberg, Sharpe and Miringoff (2002). The weights of the various domain indicators in the general index are conventional and rarely formulate a framework for a rational discussion about what these weights should be (Ioana, 2013). Economic welfare is commonly measured in terms of GDP per capita or per capita household consumption at constant currency value (Jacobs \& Slaus, 2010). GDP shortcomings, as an index for measuring socio-economic progress, feature again prominently in the public debate, following years of benign neglect. Such criticisms are almost as old as the concept itself and national accountants have repeatedly warned about limitations of GDP as a welfare indicator. At the end of the day, it is essentially a measure of economic activity, and more specifically of economic activities leading to monetary transactions. As a result, GDP suffers from two major weaknesses: (a) being a monetary aggregate, it pays little or no attention to distributional issues and to elements of human activity or well-being for which no direct or indirect market valuation is available; (b) it is measuring productive flows and, as such, ignores the impact of productive activities on stocks, including stocks of natural resources (Survey of existing approaches to measuring socioeconomic progress, April, 2008).

\subsection{Limitations of GDP as a welfare measure}

In practice, the GDP data are used to measure not only how much is produced but also to measure the well-being of the inhabitants of a country. Economists and politicians talk as if an increase in GDP means that people are better off economically. But it should be noted that when we use GDP to measure welfare there are four major problems:

1. Many products are measured not correctly because are not traded in the market, specific examples are: government services, non-commercial activities such as volunteer work and activities performed at home.

2. Accurately calculation of improved quality of goods is difficult. In particular it is noted in computers, cars etc. where quality is improved while prices have fallen rapidly.

3. Some activities represent the use of resources to avoid or limit phenomena such as crime or threats to national security.

4. GDP calculations do not take into account pollution and environmental degradation. This is very important especially in developing countries where costs associated with environmental degradation burdening the country's economic growth (Dornbusch \& Fischer, 1993).

\subsection{The role of the government}

Who decides on the welfare? In most countries, government leaders make decisions about which allocations are most desirable. By altering the efficiency with which goods are produced and distributed and the endowment of resources, governments help to determine how much is produced and how goods are allocated. Virtually every government program, tax, or action redistributes wealth (Perloff, 1999).

In modern societies and industrial welfare implies the state responsibilities to ensuring citizens with basic needs such as health care, education and housing. Another important responsibility assumed by many countries is to advance economic activity. Many states provide financial assistance to owners of factories, farmers and other producers. Some countries impose tariffs on import and export in order to stimulate domestic activity. Therefore the close cooperation between government and business is a vital element for many developed countries.

${ }^{1}$ Gini index measures the extent to which the distribution of income or consumption expenditure among individuals or households within an economy deviates from e perfectly equal distribution. A Gini index of 0 represents perfect equality while an index of 100 implies perfect inequality. 


\section{Methodology and Data}

The data for Albania is taken from World Development Indicators (World Bank). The time series data pertains to years 1992 till 2012. It is chosen a level of significance of $5 \%(\alpha=5 \%)$ in all the necessary performed tests. Administration of data is performed through SPSS 17. The assumed model is based on the expenditure approach (equation) of estimating GDP (Miller, 1999-2000). Thus the operationalization and analytical procedure is based on the following relationship model: $G D P=f(H C E, G E, G F C F, T)$. While the functional model to determine the relationship between variables is as follows:

$\mathrm{GDPt}=\beta 0+\beta 1 H C E t+\beta 2 \mathrm{GEt}+\beta 3 \mathrm{GFCFt}+\beta 4 \mathrm{Tt}+\varepsilon t$

The model consists of five variables, Gross domestic product (GDP), Household consumption expenditure (HCE), Government expenditure (GE), Gross fixed capital formation (GFCF) and Trade (T). The subscript't' represents respective variables at time t. Amongst these variables, GDP is specified as the dependent variable and the remaining four as the explanatory variables.It is expected a positive impact of all the explanatory on GDP and a negative impact of Trade as imports are greater than exports.

\subsection{Gross Domestic Product}

GDP is the total market value of all final goods and services produced by factors of production located within a nation's borders. It is the value of all final goods and services produced in an economy during a year (Perloff, 1999). Data are in current U.S. dollars.

Household consumption expenditure falls into three category: durable goods, nondurable goods and services (Miller, 1999-2000). It is the market value of all goods and services including durable products (such as cars, washing machines, and home computers), purchased by households. It excludes purchases of dwellings but includes imputed rent for owner-occupied dwellings. It also includes payments and fees to governments to obtain permits and licenses (World Bank). Data are in current U.S. dollars.

General expenditure includes all government current expenditures for purchases of goods and services including compensation of employees. It also includes most expenditure on national defense and security, but excludes government military expenditures that are part of government capital formation (World Bank). Data are in current U.S. dollars.

Gross fixed capital formation, private sector or gross private domestic investment Private investment covers gross outlays by the private sector (including private nonprofit agencies) on additions to its fixed domestic assets (World Bank). Data are expressed as \% of GDP.

\subsection{Trade}

Trade is the sum of exports and imports of goods and services measured as a share of gross domestic product (World Bank).Trade affects positively the economic performance of a country if exports are greater than imports and negatively if imports are greater than exports. Data are expressed as \% of GDP.

\section{Results}

Before running the Ordinary Least Square (OLS) Method to approximate the coefficients of the regression equation, it is tested for the stationarity of the variables. The stationarity of the time series is tested using the graphical approach, the correlogram test and the Ljung - Box Statistic under the null hypotheses that "the sum of all squared estimated autocorrelation coefficients is zero" (Gujarati, Fourth Edition). ${ }^{2}$

Each time series is tested for stationarity and it is found that all the variables are stationary at first difference I(1) while trade is stationary at second difference I(2).

${ }^{2}$ The lag of lengthbased on the rule of thumb to compute ACF is up to one-third to one-quarter the length of time series. In our model the time series are composed of 21 observations so the lag of length up to one-third of the time series length in our model is chosen seven. 


\begin{tabular}{|c|c|c|c|c|c|}
\hline & GFCF I(0) & HCE I(o) & GE I(o) & GDP I(o) & T I(0) \\
\hline Lag & Sig $^{*}$ & Sig $^{*}$ & Sig $^{*}$ & Sig $^{*}$ & Sig $^{*}$ \\
\hline 1 & .000 & .000 & .000 & .000 & .000 \\
\hline 2 & .000 & .000 & .000 & .000 & .000 \\
\hline 3 & .000 & .000 & .000 & .000 & .000 \\
\hline 4 & .000 & .000 & .000 & .000 & .000 \\
\hline 5 & .000 & .000 & .000 & .000 & .001 \\
\hline 6 & .000 & .000 & .000 & .000 & .001 \\
\hline 7 & .000 & .000 & .000 & .000 & .002 \\
\hline Conclusion & Not stationary & Not stationary & Not stationary & Not stationary & Not stationary \\
\hline
\end{tabular}

*based on the asymptotic chi-square approximation using Ljung - Box statistic

Table 3: Variables test for stationarity at I(0)

\begin{tabular}{|c|c|c|c|c|c|c|}
\hline & GFCF I(1) & HCE I(1) & GE I(1) & GDP I(1) & T I(2) & Residuals \\
\hline Lag & Sig $^{*}$ & Sig $^{*}$ & Sig $^{*}$ & Sig $^{*}$ & Sig $^{*}$ & Sig $^{*}$ \\
\hline 1 & .203 & .918 & .407 & .703 & .404 & .640 \\
\hline 2 & .147 & .984 & .319 & .637 & .464 & .866 \\
\hline 3 & .089 & .370 & .455 & .530 & .673 & .960 \\
\hline 4 & .160 & .530 & .582 & .662 & .743 & .990 \\
\hline 5 & .249 & .592 & .715 & .790 & .796 & .966 \\
\hline 6 & .255 & .594 & .722 & .599 & .841 & .985 \\
\hline 7 & .100 & .465 & .705 & .583 & .908 & .980 \\
\hline Conclusion & Stationary & Stationary & Stationary & Stationary & Stationary & Stationary \\
\hline
\end{tabular}

*based on the asymptotic chi-square approximation using Ljung - Box statistic

Table 4: Variables results of stationarity
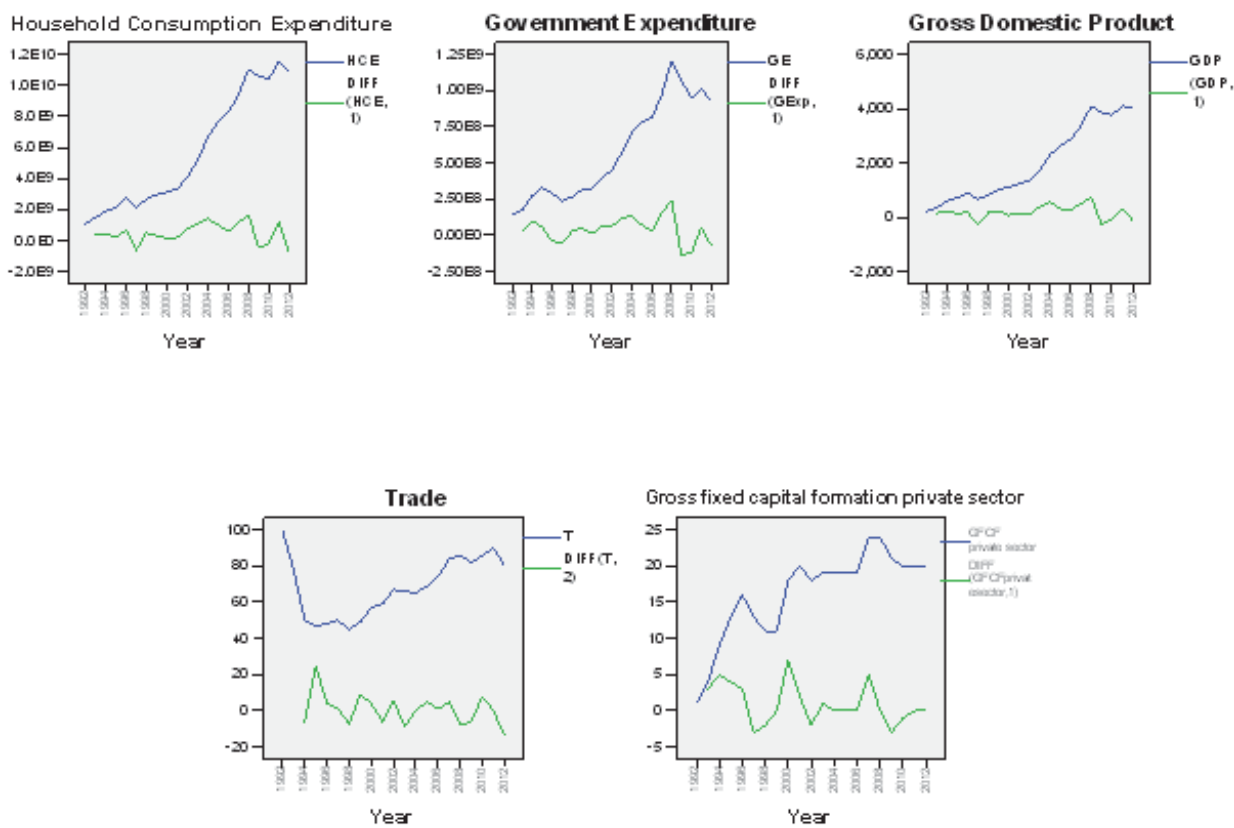

Graph 1-5: The graphical approach of time series 
Table 1: Summary results, first attempt

\begin{tabular}{lccc}
\hline Variables & Coefficients & t-Statistic & p value \\
\hline Constant & 93972452.880 & 1.439 & $.172^{*}$ \\
HCE & .741 & 5.253 & .000 \\
GE & 3.035 & 2.837 & .013 \\
GFCF & 27659961.603 & 1.365 & $.194^{*}$ \\
T & -5202784.529 & -0.858 & $.405^{*}$ \\
& & & \\
Adjusted R & & & \\
Durbin Watson Statistic & 0.931 & & \\
F-Statistic & 2.082 & & \\
Probability (F-Statistic) & 0.682 & & \\
& & & \\
\hline
\end{tabular}

*not significant

Table 2: Summary of finally results

\begin{tabular}{lccc}
\hline Variables & Coefficients & t-Statistic & P value \\
\hline Constant & 110440765.930 & 1.867 & $.078^{*}$ \\
HCE & .666 & 5.270 & .000 \\
GE & 3.906 & 4.510 & .000 \\
& & & \\
\hline Adjusted R & & \\
Durbin Watson Statistic & 0.935 & \\
F-Statistic & 1.992 & \\
Probability (F-Statistic) & 0.000 & & \\
& & & \\
\hline
\end{tabular}

*significant at $10 \%$ level of significance

The findings indicate a positive relationship between the focus variables HCE, GE, GFCF and the dependent variable GDP but a negative relationship between T and GDP (it can stand as far as imports are greater than exports in Albania). But the only significant variables remain HCE and GE. However, co-integration must exist for this relationship to be longterm. According to Engle Granger (1987) procedure, co-integration exists if theresiduals are found to be stationary (Engle \& Granger, 1987). Hence, it is employed ACF and PACF correlogram test using Ljung-Box statistic for this purpose and found to be stationary (refer last column of table 4).

\section{Conclusion}

The assumption on this paper was that GDP is the measure of welfare economics and in this way trying to find the indicators affecting GDP. The study revealed that Household Consumption Expenditure and Government Expenditure strongly and positively affect Gross Domestic Product of Albania. In such conditions we conclude that Albania's economic welfare largely depends on consumption and government expenditures according to the expenditure approach of estimating GDP. Thus increasing consumption and government expenditure our economic welfare increases as well, considering the limitations stated in literature review of using GDP as a welfare measure. 


\section{References}

Deardoff, A. V. (2006). Terms of Trade: Glossary of International Economics. Michigan: World Scientific Pub. Co. Inc.

Dornbusch, R., \& Fischer, S. (1993). Macroeconomics. Ohio, USA: McGraw Hill college.

Engle, R. F., \& Granger, C. (1987). Co-Integration and Error Correction: Representation, Estimation and Testing. Econometrica, 251276.

Gujarati, D. N. (Fourth Edition). Basic Econometrics. The McGraw - Hill Companies, 2004.

Ioana, B. (2013). An Empirical Approach on the Sustainability of Social Welfare across the European Union. Journal of Eastern Europe Research in Business \& Economics, vol. 2013

Jacobs, G., \& Slaus, I. (2010). Indicators of Welfare Progress: The power of Measuremnt and Human Welfare. CADMUS, A papers series of the South European division of the World Academy of art and science (SEED-WAAS), 53-113.

Little, I. M. (1950). A Critique of Welfare Economics. Oxford: OUP Oxford.

Mas-Collel, Andreu, Whinston, M. D., \& Green, J. R. (1995). Microeceonomic Theory. New York: Oxford University Press.

Miller, R. L. (1999-2000). Economics Today. USA: Addison-Wesley Publishing Company, Inc.

Perloff, J. M. (1999). Microeconomics. USA: Addsion Wesley Longman, Inc.

Survey of existing approaches to measuring socio-economic progress. (April, 2008). Commission on the Measurement of Economic Performance and Social Progress. Retrieved February - March 2014, from http://www.stiglitz-sen-fitoussi.fr/en/index.htm

World Bank. (n.d.). World Development Indicators. Retrieved February - March 2014, from World Bank Website: http:/www.worldbank.org/en/about 